\title{
Obesity and the Cardiorenal Metabolic Syndrome: Therapeutic Modalities and Their Efficacy in Improving Cardiovascular and Renal Risk Factors
}

\author{
Ankur Jindal $^{\mathrm{a}} \quad$ Stephen Brietzke ${ }^{\mathrm{a}} \quad$ James R. Sowers ${ }^{\mathrm{a}-\mathrm{c}}$ \\ Departments of ${ }^{a}$ Internal Medicine and ${ }^{b}$ Medical Pharmacology and Physiology, \\ University of Missouri-Columbia School of Medicine, and 'Harry S. Truman VA Medical Center, \\ Columbia, Mo., USA
}

\author{
Key Words \\ Obesity $\cdot$ Cardiorenal metabolic syndrome $\cdot$ Cardiovascular disease $\cdot$ Kidney
}

\begin{abstract}
The prevalence of obesity has increased rapidly in the United States. Obesity affects about one third of the adult population and, even though it is attributed to excess calorie intake and inadequate physical activity, its etiopathogenesis is much more complex and is an area of active study. Lifestyle modifications (with a focus on increased activity and decreased calorie intake) have modest efficacy in the treatment of obesity. There is a dearth of safe and effective therapeutic modalities to treat obesity. In this review, we discuss the role of different treatment options in the management of obesity and its comorbidities, with a focus on recently approved drugs and the emerging role of bariatric surgery.

Copyright $\odot 2012$ S. Karger AG, Basel
\end{abstract}

\section{Introduction}

Obesity is often defined as 'a condition of abnormal or excessive fat accumulation in adipose tissue, to the extent that health may be impaired' [1]. As per World Health Organization (WHO) criteria, any person with a body mass index (BMI) of 30 or more is considered obese. It is generally assumed that individuals with a BMI of 30 or above have an excess fat 


\section{CardioRenal Medicine}

\begin{tabular}{l|l}
\hline \multicolumn{2}{l}{ Cardiorenal Med 2012;2:314-327 } \\
\hline $\begin{array}{l}\text { DOI: 10.1159/000343803 } \\
\text { Published online: November 24, } 2012\end{array}$ & $\begin{array}{l}\text { ○ } 2012 \text { S. Karger AG, Basel } \\
\text { www.karger.com/crm }\end{array}$ \\
\hline $\begin{array}{l}\text { Jindal et al.: Obesity and the Cardiorenal Metabolic Syndrome: Therapeutic Modalities } \\
\text { and Their Efficacy in Improving Cardiovascular and Renal Risk Factors }\end{array}$
\end{tabular}

mass in their body [1]. However, 'BMI does not distinguish between weight associated with muscle and weight associated with fat' [1]. In fact, an athlete with a very low body fat percentage might have a BMI much higher than 25 . The relationship between BMI and body fat varies according to body build [1]. 'Indeed, a given BMI may not correspond to the degree of fatness across different populations, genders, or population subgroups' [1].

\section{Prevalence and Cost of Obesity}

According to CDC/NCHS, National Health and Nutrition Examination Survey (20092010) data, the prevalence of obesity in the United States has increased during the last decades of the 20th century [2, 3]. In 2009-2010, 35.7\% of US adults were obese [2], and approximately $6 \%$ had a BMI greater than 40 [4]. During the same period, $16.9 \%$ of US children and adolescents were obese (i.e. were at or above the 95th percentile for weight) [2]. In real numbers, this equates to 78 million adults and 12.5 million children and adolescents [2]. CDC/NCHS data suggest that, during the last decade (1999-2010), the prevalence of obesity among men has increased significantly from 27.5 to $35.5 \%$, while the prevalence of obesity among women has increased marginally from 33.4 to $35.8 \%$ [2]. Data from the CDC Behavioral Risk Factor Surveillance System (BRFSS) reveal that the percentage of obesity in the adult population had increased by 37\% between 1998 and 2006 [5]. Obesity contributes to about 112,000 preventable deaths every year in the United States [4]. Obesity affects some subgroups in the population more than others [6]. Also, absolute rates of obesity tend to be higher in those with low incomes and low education levels $[6,7]$. It has been estimated that, in 2006, per capita medical spending for obese people was USD 1,429 greater than spending for normal weight people [5]. The National Health Expenditure Accounts (NHEA) estimated that the annual medical burden of obesity could be as high as USD 147 billion per year (in 2008 dollars) [5].

Combined recommendations of BMI and waist circumference (WC) cutoff points for overweight or obesity as well as associations with disease risk for type 2 diabetes, hypertension, and cardiovascular disease (CVD) for adults are compiled in table 1 [7]. Thus, increasing $\mathrm{BMI}$ and $\mathrm{WC}$ contribute to progressive increases in CVD risk.

\section{CVD Risk and Obesity}

In 1947, Keys [8] began a monumental study, which spanned seven countries and made all previous attempts at identifying the risk factors for coronary disease look minuscule. In his seven-country study, Keys concluded that a 10-year incidence of coronary heart disease showed no consistent relation with either relative weight or relative fatness. In the latter half of the 20th century, the attitude of governments and the WHO toward obesity and its associated risks began to change, and the WHO started the MONICA surveys for monitoring global CVD trends in middle-aged men and women [9]. The MONICA project also provides the most comprehensive data on the prevalence of obesity and its relationship to CVD [1].

Contrary to old beliefs, obesity is now considered a key risk factor for coronary heart disease, stroke, and non-insulin-dependent diabetes [1]. Many studies have failed to accurately assess the impact of obesity on premature mortality and CVD. Furthermore, most of these studies have failed to eliminate biases from their design [1]. The Nurse's Health Study reported that, when biases were removed, there was an almost linear, continuous relationship between obesity and mortality $[1,10]$. Many cross-sectional surveys have demonstrated an association between the prevalence of obesity and the prevalence of hypertension, and have 
Table 1. Categories of BMI and disease risk relative to normal weight and WC

\begin{tabular}{|c|c|c|c|c|}
\hline & \multirow[t]{2}{*}{ BMI } & \multirow{2}{*}{$\begin{array}{l}\text { Obesity } \\
\text { class }\end{array}$} & \multicolumn{2}{|c|}{ Disease risk (relative to normal weight and WC) } \\
\hline & & & $\begin{array}{l}\text { men }<102 \mathrm{~cm} / \\
\text { women }<88 \mathrm{~cm}\end{array}$ & $\begin{array}{l}\text { men }>102 \mathrm{~cm} / \\
\text { women }>88 \mathrm{~cm}\end{array}$ \\
\hline Underweight & $<18.5$ & & & \\
\hline Normal & $18.5-24.9$ & & & \\
\hline Overweight & $25.0-29.9$ & & increased & high \\
\hline Obesity & $30.0-34.9$ & I & high & very high \\
\hline & $35.0-39.9$ & II & very high & very high \\
\hline Extreme obesity & $>40.0$ & III & extremely high & extremely high \\
\hline
\end{tabular}

Source: NHLBI Obesity Education Initiative, 2000.

established obesity as a risk factor for the development of hypertension [11, 12]. In addition, obese people are at a higher risk of having a metabolic dyslipidemic state with low high-density lipoprotein (HDL), high triglycerides, and increased levels of small dense low-density lipoprotein (LDL) $[1,13]$. It has been shown that abdominal adiposity also correlates with this metabolic dyslipidemia, independent of total body fat mass. Italian investigators studied the effect of BMI and WC on the incidence of CVD events and all-cause CVD mortality in randomly selected subjects from the general population of Monza, Italy, over a 148-month follow-up period [14]. Data from this study showed that progressive increases in BMI and WC were associated with a progressive increase in systolic and diastolic blood pressures and metabolic markers of CVD such as serum cholesterol, triglycerides, and blood glucose. Others analyzed prospective studies with 2 million participants and concluded that there was a graded positive relationship of overweight and obesity with the incidence of ischemic stroke [15]. In this regard, a meta-analysis showed that overweight is an independent risk factor for coronary heart disease, and that the elevations in cholesterol and blood pressure related to obesity do not completely explain the increased risk of heart disease associated with overweight [16]. It was concluded that even moderate overweight is associated with an increased risk of coronary heart disease [16].

It has recently been suggested that the increased CVD risk might be related to a state of low-grade inflammation, endothelial dysfunction, hemostatic imbalance, impaired endothelial vasodilatory response, left ventricular hypertrophy, and reduced heart rate variability due to withdrawal of vagal activity and predominance of sympathetic activity $[16,17]$ (fig. 1). Some studies have provided very convincing data to support the association between obesity and CVD, hypertension, and type 2 diabetes [7]. The Framingham Heart Study ranked body weight as the third most important predictor of coronary heart disease among males $[1,11,18]$. BMI has traditionally been used as a measure of obesity. Many experts feel that measurements of central adiposity such as WC and waist-hip ratio might be better predictors of CVD risk $[7,17]$. Typically, the use of WC is favored over the use of the waist-hip ratio due to the relative ease of WC measurement [7]. A number of studies have demonstrated that people who had a more central localization of fat were at a higher risk for diabetes and hypertriglyceridemia compared to people who had a more peripheral distribution of fat. Thus, it is plausible that WC and BMI, when used together, might better predict the risk for CVD [17]. 


\section{CardioRenal Medicine}

\begin{tabular}{l|l}
\hline Cardiorenal Med 2012;2:314-327 \\
\hline DOl: 10.1159/000343803 & $\begin{array}{l}\text { @ 2012 S. Karger AG, Basel } \\
\text { www.karger.com/crm }\end{array}$ \\
\hline Published online: November 24, 2012 &
\end{tabular}

Jindal et al.: Obesity and the Cardiorenal Metabolic Syndrome: Therapeutic Modalities and Their Efficacy in Improving Cardiovascular and Renal Risk Factors

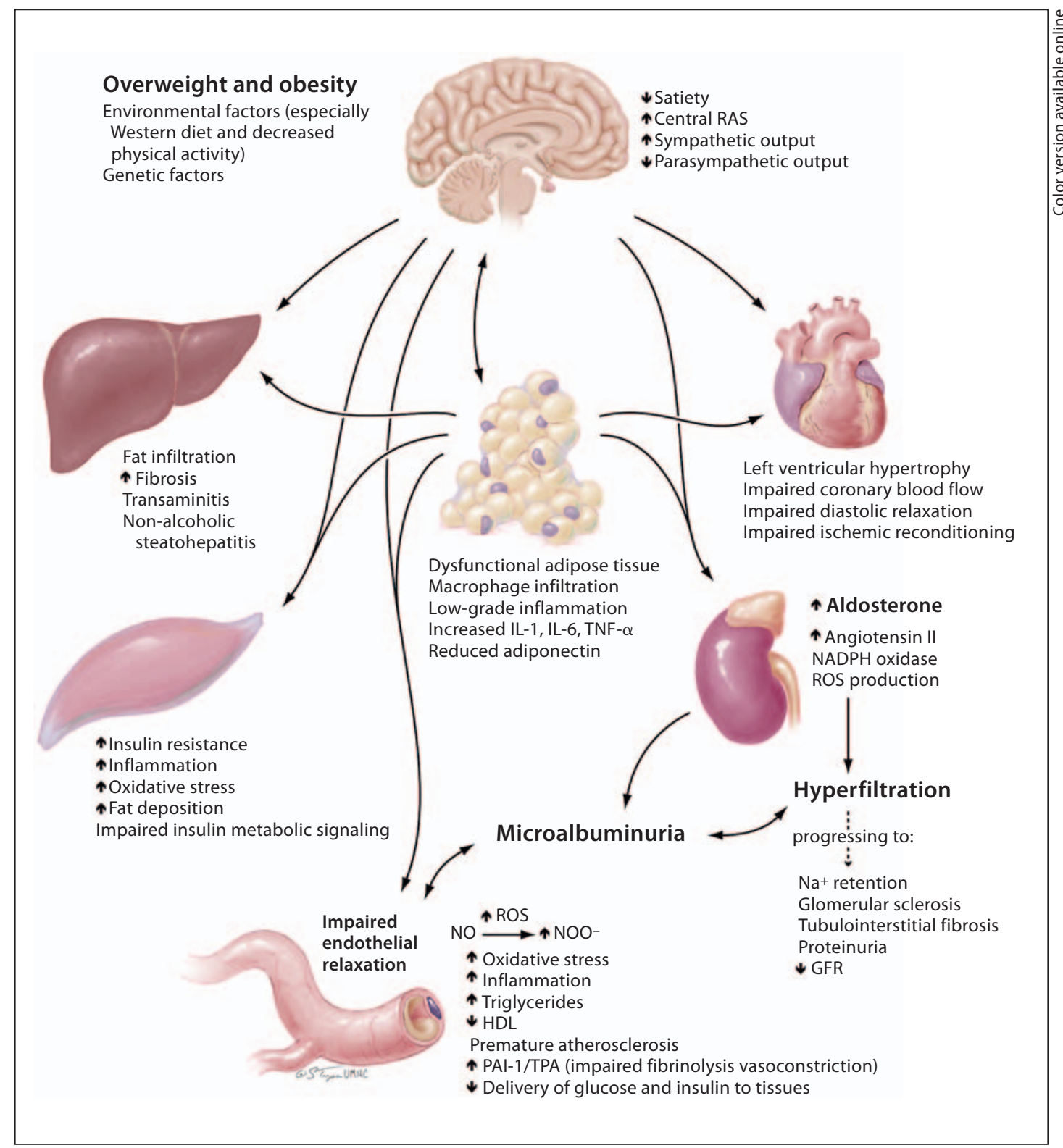

Fig. 1. Mechanisms by which obesity promotes the cardiorenal metabolic syndrome. The scheme shows the complex environmental, behavioral, hormonal, and genetic interactions which help modify an individual's body weight, and further shows the effects of the resultant dysfunctional adipose tissue and lowgrade inflammation on the structure and function of different organ systems.

\section{Obesity and Renal Disease}

Studies have suggested a possible relationship between obesity and renal damage and/or chronic renal failure in patients with or without diabetes, hypertension, or pre-existing renal disease [19]. A study conducted in Japan showed an association between BMI and the development of end-stage renal disease in men [20]. The authors also postulated that the maintenance of optimal weight might reduce the risk for development of end-stage renal disease. Many studies have shown an increased prevalence of albuminuria in obese people $[6,21]$, and 


\section{CardioRenal Medicine}

\begin{tabular}{l|l}
\hline \multicolumn{2}{l}{ Cardiorenal Med 2012;2:314-327 } \\
\hline $\begin{array}{l}\text { DOI: 10.1159/000343803 } \\
\text { Published online: November 24, } 2012\end{array}$ & $\begin{array}{l}\text { @ 2012 S. Karger AG, Basel } \\
\text { www.karger.com/crm }\end{array}$ \\
\hline $\begin{array}{l}\text { Jindal et al.: Obesity and the Cardiorenal Metabolic Syndrome: Therapeutic Modalities } \\
\text { and Their Efficacy in Improving Cardiovascular and Renal Risk Factors }\end{array}$
\end{tabular}

additional studies have shown that weight loss might have a beneficial effect on albuminuria/ proteinuria in this group of individuals $[22,23]$. Furthermore, hyperfiltration, with glomerular filtration rate (GFR) values up to $40 \%$ above normal, has been reported in obese people [24]. However, these values, when corrected for body surface area, have been found to be in the normal range for healthy obese subjects [24]. This would imply a higher than normal single nephron glomerular filtration rate in obese individuals. Thus, obesity/visceral adiposity results in renal damage, in part, by causing hyperfiltration, which is thought to be suggestive of elevated glomerular capillary pressure, which in turn has been shown to be a crucial mediator of glomerular capillary damage in rodent models [6].

Obesity is known to be associated with insulin resistance in patients with or without diabetes. It has been shown that hyperinsulinism in conjunction with hypertension can cause renal parenchymal changes (including glomerulosclerosis and tubulointerstitial injury) and can affect sodium handling by the kidney [25].

\section{Approach to the Treatment of Obesity to Reduce CVD and Renal Disease}

It has been suggested that an underlying cause of obesity is a small but prolonged incremental positive energy balance [26]. If sustained over long periods of time, even very small differences between energy intake and energy expenditure can lead to significant weight gain. One of the crucial parts of any approach to weight loss is setting a reasonable initial target goal. In 1998, the National Institute of Health (NIH) published guidelines for the identification, evaluation, and treatment of obesity in adults [27]. These guidelines recommended an initial weight loss goal of $10 \%$ of the baseline body weight over a period of 6 months as this is an achievable goal and can significantly decrease the severity of obesity-related risk factors. Further weight loss can be considered once these initial targets have been achieved. Many patients successfully achieve their goal weight, but they are unable to maintain it. Continued support with behavior modification therapy to encourage healthy diet and regular physical activity has been shown to be beneficial.

A multimodal approach is needed for effective weight loss and for maintenance of weight loss. Some key points emphasized in the NIH clinical guidelines for the evaluation and treatment of obesity are as follows [27]:

(1) A low-calorie diet (LCD; 800-1,200 kcal/day) can reduce total body weight by an average of $8 \%$ over 6 months and can help reduce abdominal fat.

(2) A very-low-calorie diet (VLCD; 250-800 kcal/day) produces greater initial weight loss than a LCD, but long-term weight loss at $>1$ year is similar with both diets.

(3) Aerobic exercises result in modest weight loss and may reduce abdominal fat in overweight and obese adults. It may also improve cardiorespiratory fitness.

(4) Reduced calorie intake and increased physical activity, when used in combination, produce greater weight loss than the use of either modality alone.

(5) When behavior therapy is used in combination with other weight loss approaches, it provides additional short-term benefits.

(6) Pharmacological therapy for obesity should only be used as part of a comprehensive weight loss program (including diet and physical activity) for patients with a BMI of $\geq 30$ with no concomitant obesity-related risk factors, or for patients with a BMI of $\geq 27$ with concomitant obesity-related risk factors or diseases.

(7) Bariatric surgery is an option for severely obese patients (BMI $\geq 40$ or $\geq 35$ with comorbid conditions) who are at high risk of obesity-related morbidity and who have failed a trial of less invasive interventions. 


\section{CardioRenal Medicine}

(8) The initial goal of weight loss therapy should be to reduce body weight by approximately $10 \%$ from baseline weight.

(9) Target weight loss should be approximately 1-2 pounds/week for a period of 6 months.

(10) Initially, moderate levels of physical activity for 30-45 min at least 3-5 days per week should be encouraged.

\section{The Role of Diet in the Treatment of Obesity}

Dietary manipulation is a very important part of the multifaceted approach to weight loss. The ideal weight loss diet should provide all the essential nutrients in the right proportions but still create an energy deficit. In addition, this diet should take the dietary preferences of the patient into account and should be sustainable in the long term. Weight loss diets can be classified according to their energy content. LCDs have a calorie content of $800-$ $1,500 \mathrm{kcal} /$ day, whereas VLCDs have an energy content of $<800 \mathrm{kcal} /$ day. LCDs and VLCDs have been shown to have similar efficacies for weight loss over the long term $(>1$ year) in multiple clinical trials $[27,28]$, but VLCDs place patients at a higher risk of complications such as electrolyte abnormalities, micronutrient deficiencies, gallstones, etc. Long-term compliance with VLCDs is difficult. Many randomized controlled trials (RCTs) have compared weight loss with low- and high-carbohydrate diets, when total energy content was kept constant. These studies did not find any significant difference in weight loss with either diet at 12 weeks [29].

Multiple RCTs have compared weight loss in patients on an isocaloric low-fat diet or lowcarbohydrate diet [29]. These RCTs have failed to show any significant difference in percentage weight loss in the two groups. For example, investigators conducted an RCT to evaluate effects of a 2-year treatment with low-carbohydrate or low-fat diets [30]. In this trial, both diet groups achieved identical weight loss (11\% at 6 months and $7 \%$ at 24 months). The lowcarbohydrate group had a greater increase in HDL at 24 months compared to the low-fat group. Multiple other studies have found that, even though a low-carbohydrate diet achieved greater weight loss at 6 months compared to a low-fat diet, the difference in weight loss was not significant at 1 year [30-36]. Popular low-carbohydrate diets include the Atkins diet, Bernstein diabetes diet, Caveman diet, Protein Power diet, Sonoma diet, South Beach diet, Sugar Busters diet, Zone diet, and others [35]. The effects of a low-carbohydrate diet on LDL, HDL, triglycerides, and glycemic control were not consistent in various trials and meta-analyses [35].

An important strategy in weight loss is to understand the source of calories in the diet. A practical way to reduce the calorie content in the diet is to reduce the fat and alcohol consumption. Efforts should be made to modify the diet to reduce the CVD risk factors. While making dietary modifications, a patient's dietary preferences should also be taken into consideration as patients are more likely to be compliant with dietary plans when they include preferred food items. In 2008, the American Diabetes Association stated that 'optimal macronutrient distribution of weight loss diets has not been established' [37]. The NIH clinical guidelines also noted that, for overweight patients with a BMI of 27-35, a 300- to 500-kcal/ day reduction in energy intake will lead to a weight loss of $0.5-1$ pound per week [27]. For more severely obese patients $(\mathrm{BMI}>35)$, deficits of $500-1,000 \mathrm{kcal} /$ day will lead to a weight loss of 1-2 pounds per week [27]. These energy deficits will result in approximately $10 \%$ weight loss over 6 months. Current data are not sufficient to establish the optimal macronutrient composition of a diet but they suggest that the efficacy of LCDs in weight loss is similar to that of VLCDs, and that the use of LCDs appears to be safer. 


\section{CardioRenal Medicine}

\begin{tabular}{l|l}
\hline Cardiorenal Med 2012;2:314-327 \\
\hline $\begin{array}{l}\text { DOI: 10.1159/000343803 } \\
\text { Published online: November 24, } 2012\end{array}$ & $\begin{array}{l}\text { ○ } 2012 \text { S. Karger AG, Basel } \\
\text { www.karger.com/crm }\end{array}$ \\
\hline $\begin{array}{l}\text { Jindal et al.: Obesity and the Cardiorenal Metabolic Syndrome: Therapeutic Modalities } \\
\text { and Their Efficacy in Improving Cardiovascular and Renal Risk Factors }\end{array}$
\end{tabular}

Table 2. Criteria for pharmacological therapy of obesity $[27,40]$

BMI $\geq 30$ without obesity-related risk factors or BMI $\geq 27$ in association with significant obesity-related risk factors

Drugs may only be used as part of a comprehensive weight loss program

Should never be used without concomitant lifestyle modifications

For continued treatment, patients should have a weight loss of $\geq 4$ pounds per month for each of the first 3 months

\section{The Role of Exercise in the Treatment of Obesity}

Exercise or increased physical activity addresses the problem of obesity by increasing the energy expenditure, thus reducing the imbalance between excessive calorie intake and decreased calorie use. In the modern world, high-energy and high-fat food is available without difficulty and at low cost. The positive energy balance created by excessive calorie intake is so high that it cannot be easily overcome by moderate-intensity exercise. For example, to burn 1 pound of fat per week, about $500 \mathrm{kcal}$ energy deficits will need to be created every day for 1 week. This would mean running 45 min every day for 1 week at a speed of $6 \mathrm{mph}$ [27, 29]. Such intense exercise is not recommended for many people with obesity due to their medical comorbidities. A meta-analysis and systematic review of RCTs revealed that aerobic exercise programs of moderate intensity resulted in modest reductions in weight and WC [38]. These programs had durations from 12 weeks to 12 months. Moderate-intensity aerobic exercise programs provide modest improvements in cardiovascular risks and lipid levels, even though these programs (as independent interventions) are not effective tools for weight loss in overweight and obese people. In another meta-analysis, it was found that exercise had a modest blood pressure-lowering effect, and that the beneficial effect was more pronounced in overweight people than in obese people [39]. Diet has been found to be more effective than exercise in decreasing both BMI and blood pressure. In addition, diet alone was as effective as the combination of diet and exercise in reducing blood pressure, but the combination was superior in decreasing weight [39].

\section{The Role of Pharmacotherapy in the Treatment of Obesity}

The criteria for pharmacotherapy are given in table 2. The search for an obesity 'wonder drug' has not been successful thus far. Drugs introduced to date have failed to live up to the expectations due to either poor efficacy or a bad risk profile. Many of these medications had to be withdrawn from the market because of unacceptable risks, which often became evident in post-marketing trials. Treatment response to weight loss medications is variable. Some people have above-average weight loss with these medications, while others do not experience significant weight loss. Studies using weight loss drugs have shown that initial non-responders are unlikely to respond to increased doses of weight loss medications [27]. If a patient does not lose $2 \mathrm{~kg}$ during the first 4 weeks after initiating treatment, the likelihood of success with a weight loss drug is considered low [27, 40]. 


\section{CardioRenal Medicine}

\section{Drugs Used to Promote Weight Loss}

Phentermine

Phentermine is an anorectic agent and an adrenergic reuptake inhibitor which was approved for short-term treatment of obesity in 1968 [26]. It is a derivative of phenylethylamine, which is a precursor of amphetamine. Phentermine promotes weight loss by activation of the sympathetic nervous system, which decreases food intake and increases resting energy expenditure [40]. Phentermine is classified by the FDA as a Schedule IV drug. It carries a risk for addiction and/or habituation, though its abuse potential is considered very low [26, 40]. Its use for weight loss is approved only for the short term (up to 12 weeks). Phentermine use can cause tachycardia, palpitation, and hypertension [40] and is contraindicated in patients with coronary artery disease, congestive heart failure, stroke, and uncontrolled hypertension. There are no long-term data suggesting that treatment with this agent reduces CVD or renal disease.

Orlistat

Orlistat binds and inhibits lipase in the human gastrointestinal tract. It prevents the breakdown of ingested fats into absorbable fatty acids. The fat malabsorption due to orlistat ingestion is directly related to the dose of orlistat. Many long-term studies (at least 1-year follow-up) have evaluated the efficacy of orlistat in the treatment of obesity [41, 42]. A metaanalysis of RCTs showed that the participants treated with orlistat lost approximately $2.7 \mathrm{~kg}$ more weight than those treated with placebo [43]. The meta-analysis also showed that significantly more people were able to lose $5-10 \%$ of their body weight while on orlistat compared to placebo [43]. In the Swedish Multimorbidity Study, the authors concluded that treatment with orlistat in addition to dietary modifications produced significantly greater mean weight loss (5.9\% in non-diabetics and $4.6 \%$ in diabetics) and CVD risk factor reduction than treatment with dietary modifications alone [44]. Weight loss with orlistat has been associated with improvement in comorbidities of obesity [45-47].

Sibutramine

Results of the Sibutramine Cardiovascular Outcomes (SCOUT) trial indicated that sibutramine increased - rather than decreased - the risk of cardiovascular events. Sibutramine was withdrawn from the US market on October 8, 2010 [48].

\section{Lorcaserin}

Lorcaserin hydrochloride (Belviq), a selective agonist of 5-HT2C (serotonin receptor), was approved by the FDA on June 27, 2012, as an adjunct to lifestyle modifications for chronic weight management. Lorcaserin is believed to cause weight loss by decreasing hunger and increasing satiety. It decreases daily calorie intake by about $250 \mathrm{kcal}$ but does not affect energy expenditure [49].

The safety and efficacy of lorcaserin were studied in three RCTs, which enrolled a total of 7,794 overweight or obese patients and studied the effects of lorcaserin for 1-2 years [4951]. In the Behavioral Modification and Lorcaserin for Overweight and Obesity Management (BLOOM) study, $47.5 \%$ of the participants in the lorcaserin group lost $5 \%$ or more of their baseline body weight compared to $20.3 \%$ of the participants in the placebo group. This study also showed that a greater percentage of people maintained their weight loss if they were continued on lorcaserin beyond 1 year [51]. The weight loss achieved with lorcaserin was associated with decreased WC and decreased levels of markers of inflammation, along with improvement in serum lipid levels, insulin resistance, and blood pressure [51]. The results of the Behavioral Modification and Lorcaserin Second Study for Obesity Management (BLOSSOM), which included 4,008 patients, were consistent with the results of the BLOOM trial 


\section{CardioRenal Medicine}

[49]. The BLOSSOM trial also established that weight loss with lorcaserin was dose dependent. In the BLOOM-DM trial, the investigators studied the efficacy and safety of lorcaserin for weight loss in patients with type 2 diabetes [50]. The participants of BLOOM-DM who took lorcaserin for 1 year lost on average $5.5 \%$ of their baseline body weight. The weight loss was observed to be more significant in Caucasians compared to African-Americans or Hispanics in the BLOSSOM trial [49].

One of the concerns with serotonin agonists is valvulopathy, especially the thickening of mitral and/or aortic valves, and valvular insufficiency [51]. Serotonin-associated valvulopathy is thought to be related to the activation of serotonin $2 \mathrm{~B}$ receptors in the valvular interstitial cells, an effect seen with fenfluramine. Lorcaserin is a selective serotonin $2 \mathrm{C}$ agonist, and in trials the incidence of FDA-defined valvulopathy and valvular insufficiency was not found to be significantly different between the study groups. The medication should be discontinued in patients who fail to lose $5 \%$ of their baseline body weight after 12 weeks of treatment.

Phentermine and Topiramate Extended Release (Qsymia)

Within days of the approval of lorcaserin, Qsymia (phentermine and topiramate extended release) was approved by the FDA for chronic weight management. Qsymia's efficacy and safety were evaluated in two RCTs (CONQUER [52] and EQUIP [53]), which together enrolled 3,734 subjects and studied the effects of Qsymia over 56 weeks. An extension study (SEQUEL [54]) was also performed to evaluate the long-term efficacy and safety of Qsymia. In the EQUIP trial, two doses of Qsymia were evaluated, 3.75/23, a low-dose combination, and 15/92, a high-dose combination. Analysis of data from the EQUIP trial showed that Qsymia is an effective weight loss drug, and that weight loss with Qsymia has favorable effects on cardiovascular and metabolic risk factors. Weight loss, some of the metabolic and cardiovascular benefits, as well as some of the adverse effects were noted to be dose related [53].

The CONQUER trial further evaluated the effects of Qsymia-induced weight loss on weight-related comorbidities. Effects of 7.5/46 and 15/92 strength combinations were studied and compared. In this trial, participants with mild depressive symptoms were also included. The CONQUER trial validated the results of the EQUIP trial and showed that approximately $50 \%$ of the participants treated with high-dose Qsymia lost at least $10 \%$ of their baseline body weight over a period of 56 weeks [52]. Qsymia 15/92 was associated with a 14.4\% weight loss in study completers, which appears to be higher than that with any other approved pharmacological treatment [53]. To validate this finding, further studies and head-to-head trials will be needed in the future. The SEQUEL study (a phase 3 extension study) showed that the beneficial effects of treatment of overweight and obesity with Qsymia, as reported in the CONQUER trial, were sustained over a 108-week period, if the treatment was continued [54]. An increase in heart rate was noted in participants taking the drug [53]. The increase in heart rate could be related to the sympathomimetic action of phentermine. The effect of this increase on cardiovascular risk factors is unclear. The FDA does not recommend the use of this drug in patients with recent stroke, unstable heart disease, or hyperthyroidism.

Naltrexone-Bupropion Extended Release

This combination is not yet approved for marketing in the United States. The safety and efficacy of this combination were studied in four large, multicenter, placebo-controlled RCTs (COR-1, COR -2, COR-Diabetes, COR-BMod) [26, 55]. Bupropion reduces food intake by acting on adrenergic and dopaminergic receptors [26]. Naltrexone is a mu-opioid receptor antagonist. The combination was developed to produce complementary actions in the central nervous system pathways that regulate weight [56]. Studies have shown that the combi- 


\section{CardioRenal Medicine}

\begin{tabular}{|c|c|}
\hline Cardiorenal Med 2012;2:314-327 & \\
\hline $\begin{array}{l}\text { DOI: } 10.1159 / 000343803 \\
\text { Published online: November 24, } 2012\end{array}$ & $\begin{array}{l}\text { (c) } 2012 \text { S. Karger AG, Basel } \\
\text { www.karger.com/crm }\end{array}$ \\
\hline
\end{tabular}

Table 3. Medication for intentional weight loss

\begin{tabular}{|c|c|c|c|}
\hline Medication & Dosage for adults & Common adverse effect & $\begin{array}{l}\text { Contraindications/ } \\
\text { caution if }\end{array}$ \\
\hline Phentermine & $15-37.5 \mathrm{mg} /$ day & $\begin{array}{l}\text { Tachycardia, palpitation, } \\
\text { hypertension }\end{array}$ & $\begin{array}{l}\text { Coronary artery disease, stroke, } \\
\text { uncontrolled hypertension, } \\
\text { pregnancy }\end{array}$ \\
\hline Orlistat & 120 or $60 \mathrm{mg}$ t.i.d. & $\begin{array}{l}\text { Flatulence, fatty stools, } \\
\text { vitamin deficiencies }\end{array}$ & $\begin{array}{l}\text { Chronic malabsorption } \\
\text { syndrome, pregnancy }\end{array}$ \\
\hline Belviq & 10 mg b.i.d. & Headache, dizziness & $\begin{array}{l}\text { Risk of serotonin syndrome, } \\
\text { pregnancy }\end{array}$ \\
\hline Qsymia & $\begin{array}{l}\text { 7.5/46 daily or } \\
15 / 92 \text { daily }\end{array}$ & $\begin{array}{l}\text { Paresthesia, dry mouth, } \\
\text { neuropsychiatric } \\
\text { symptoms }\end{array}$ & $\begin{array}{l}\text { Hyperthyroidism, glaucoma, } \\
\text { recent or unstable heart disease, } \\
\text { pregnancy }\end{array}$ \\
\hline Liraglutide & $\begin{array}{l}0.6-1.8 \mathrm{mg} / \text { day for } \\
\text { treatment of diabetes; } \\
\text { not FDA approved for } \\
\text { treatment of obesity yet }\end{array}$ & $\begin{array}{l}\text { Nausea, diarrhea, } \\
\text { headache }\end{array}$ & $\begin{array}{l}\text { History or family history of } \\
\text { medullary thyroid cancer, } \\
\text { pregnancy }\end{array}$ \\
\hline $\begin{array}{l}\text { Naltrexone- } \\
\text { bupropion } \\
\text { extended release }\end{array}$ & Not FDA approved yet & $\begin{array}{l}\text { Nausea, headache, } \\
\text { tremor }\end{array}$ & No FDA recommendations yet \\
\hline
\end{tabular}

nation produced a statistically significant and clinically meaningful weight loss and improvement in cardiorenal metabolic risk factors over placebo [55-58]. The most commonly reported adverse events included nausea, constipation, headache, and insomnia. The adverse events associated with the combination were generally mild to moderate in severity and usually self-limiting [56]. A small increase in systolic and diastolic blood pressure was noted after therapy initiation in the participants on the drug combination. This increase in blood pressure was attributed to the effects of bupropion. With weight loss, blood pressure decreased below the baseline in the group treated with the combination, but the drop in blood pressure was less than that observed in the placebo group [56].

\section{Liraglutide}

Liraglutide is a glucagon-like peptide-1 (GLP-1) analogue. It has a 97\% structural homology to human GLP-1 $[26,59]$. Liraglutide was developed and approved for the treatment of type 2 diabetes mellitus. Native GLP-1 decreases appetite and energy intake in normalweight and obese individuals $[59,60]$. A pilot study was conducted to study the effects of liraglutide in the treatment of obesity [59]. This placebo-controlled RCT compared treatment effects of different doses of liraglutide to the effects of placebo or orlistat. The study showed a clinically significant, dose-dependent weight loss in the subjects treated with liraglutide [59]. Over 20 weeks of treatment, the weight loss was greater in the liraglutide group than in the placebo or orlistat group. More than $50 \%$ of the participants treated with liraglutide lost $5-10 \%$ of their baseline body weight. In addition, liraglutide had beneficial effects on pre-diabetes, WC, and blood pressure [59]. Further studies are being conducted to evaluate the efficacy and safety of liraglutide for the treatment of obesity and its impact on CVD and renal disease [26].

All of the above-discussed medical treatments are summarized in table 3. 


\section{CardioRenal Medicine}

\begin{tabular}{|c|c|}
\hline Cardiorenal Med 2012;2:314-327 & \\
\hline $\begin{array}{l}\text { DOI: } 10.1159 / 000343803 \\
\text { Published online: November } 24,2012\end{array}$ & $\begin{array}{l}\text { @ } 2012 \text { S. Karger AG, Basel } \\
\text { www.karger.com/crm }\end{array}$ \\
\hline
\end{tabular}

\section{The Role of Surgery in the Treatment of Obesity}

Bariatric surgical procedures decrease body weight by limiting the caloric intake and/or by decreasing the absorption of nutrients. The criteria for surgical treatment of obesity are [27]: (1) clinically severe obesity, i.e. BMI $\geq 40$ or $\geq 35$ with comorbid conditions; (2) failure of less invasive procedures, and (3) high risk of obesity-associated morbidity and mortality.

Bariatric surgical procedures include the Roux-en-Y gastric bypass and laparoscopic adjustable gastric banding, the most frequently performed bariatric surgeries [61]. Bariatric surgery is considered the most effective treatment for morbid obesity and is now being performed more frequently than in the past. The efficacy of bariatric surgery for weight loss and the treatment of diabetes has been demonstrated in many studies [62], but high-quality data from large, adequately powered long-term RCTs regarding the effects of bariatric surgery on mortality and CVD are lacking. In a meta-analysis, Padwal et al. [61] concluded that diversionary procedures were more efficacious for weight loss than restrictive procedures. When comparing these results (or results for bariatric surgeries in general) to those of other treatment modalities for obesity, it is important to understand the difference between excess weight loss and weight loss. Excess weight is defined as the total preoperative weight minus the ideal body weight. Most of the data on the efficacy of bariatric surgeries report weight loss in terms of excess body weight loss, while the data on the efficacy of other treatment modalities (i.e. diet, pharmacotherapy, etc.) report weight loss in terms of total body weight loss. For the same absolute weight loss, the excess weight loss percentage will be greater than the total body weight loss percentage.

There is a significant improvement in symptoms and manifestations of diabetes, obstructive sleep apnea, hypertension, and hyperlipidemia in patients who underwent bariatric surgery $[63,64]$. Recent studies have demonstrated a weight loss-dependent resolution or improvement in diabetes among patients who underwent bariatric surgery [63-65]. In this meta-analysis, $62 \%$ of diabetic patients were found to remain diabetes free 2 years after bariatric surgery [63]. The improvement in diabetes was more marked with the procedures associated with greater excess body weight loss [63]. In some patients, the blood glucose improves or normalizes within days after gastric bypass, even before there is significant weight loss. The mechanism of this change is not clear, but it could be related to hormonal changes in the gut $[63,66]$. Other studies have reported that the resolution of diabetes after bariatric surgery is associated with a decrease in mortality among diabetic patients [63, 67]. Bariatric surgery appears to be a very promising intervention for obesity and, not surprisingly, the number of bariatric surgeries performed worldwide is increasing rapidly. However, there are a number of complications associated with bariatric surgery, including underappreciated nutritional deficiencies [68] and postoperative acute kidney failure after gastric bypass [69].

\section{Cardiovascular Effects and Benefits of Weight Loss}

In a 2-year study, it has been demonstrated that weight loss is associated with beneficial changes in cardiovascular structure and function [70]. The authors noted a decrease in the left ventricular mass, improvement in diastolic and systolic function, and a decrease in vascular hypertrophy in the participants who attained modest weight loss. The authors also observed that, even though the maximal weight loss occurred at 6 months, the maximal cardiovascular benefits occurred much later and usually lagged the maximal weight loss by 3-12 months. Any weight regain after the weight loss led to a reversal of the improved cardiovascular markers [70]. In an observational analysis of the Look Action For Health in Diabetes (AHEAD) trial, it was observed that even a modest weight loss of $5-10 \%$ can produce clini- 


\section{CardioRenal Medicine}

cally relevant improvements in cardiovascular risk factors, glycemic control, blood pressure, HDL, and triglycerides [71]. Various studies have shown the efficacy of weight loss by lifestyle modifications, pharmacotherapy, and bariatric surgery, or by any combination of these modalities, in mitigating the cardiovascular risk factors associated with obesity.

Current studies suggest that bariatric surgery has substantial beneficial effects for patients with obesity and obesity-related comorbidities. Studies directly comparing the beneficial effects of pharmacotherapies, lifestyle modifications, and bariatric surgery are lacking. The available data indicate that the efficacy of lifestyle modifications and pharmacotherapy for the treatment of obesity is modest at best for most patients. Recently, a few new medications have been approved for the treatment of obesity. There is some evidence that recently approved medications might be more efficacious than the older medications. However, these newer medications and drug combinations have not been studied in post-marketing trials yet. The phase 3 trials had some limitations; the study populations were not representative of the general population pool as there was a lack of ethnic and/or gender diversity. More studies and long-term trials are required to compare the relative efficacy of the different treatment options. Trials that compare the different treatment modalities to each other might help design better and more efficacious treatment plans in the future.

\section{Acknowledgments}

This research was supported by the NIH (R01 HL73101-01A1 and R01 HL107910-01 to J.R.S.) and the Veterans Affairs Merit System 0019 (to J.R.S.). The authors would like to thank Stacy Turpin for the illustration and Brenda Hunter for her assistance in editing the manuscript.

\section{Disclosure Statement}

The authors have no conflict of interest to disclose.

\section{References}

1 WHO Consultation on Obesity: Obesity: preventing and managing the global epidemic: report of a WHO consultation. WHO technical report series 894. Geneva, WHO, 1999.

2 Ogden CL, Carroll MD, Kit BK, Flegal KM: Prevalence of obesity in the United States, 2009-2010. NCHS Data Brief 2012;82:1-8

-3 Flegal KM, Carroll MD, Kit BK, Ogden CL: Prevalence of obesity and trends in the distribution of body mass index among US adults, 1999-2010. JAMA 2012;307:491-497.

4 U.S. Department of Health and Human Services: The Surgeon General's Vision for a Healthy and Fit Nation. Rockville, U.S. Department of Health and Human Services, Office of the Surgeon General, January 2010.

5 Finkelstein EA, Trogdon JG, Cohen JW, Dietz W: Annual medical spending attributable to obesity: payer- and servicespecific estimates. Health Aff (Millwood) 2009;28:w822-w831.

6 Sowers JR, Whaley-Connell A, Hayden MR: The role of overweight and obesity in the cardiorenal syndrome. Cardiorenal Med 2011;1:5-12.

7 Waist circumference and waist-hip ratio: report of a WHO Expert consultation. Geneva, WHO, 2008.

8 Keys A: Seven Countries. A Multivariate Analysis of Death and Coronary Heart Disease. Cambridge, Harvard University Press, 1980.

$\checkmark 9$ James WP: WHO recognition of the global obesity epidemic. Int J Obes (Lond) 2008;32(suppl 7):S120-S126.

10 Manson JE, Willett WC, Stampfer MJ, Colditz GA, Hunter DJ, Hankinson SE, et al: Body weight and mortality among women. N Engl J Med 1995;333:677-685.

11 Wilson PW, D’Agostino RB, Sullivan L, Parise H, Kannel WB: Overweight and obesity as determinants of cardiovascular risk: the Framingham experience. Arch Intern Med 2002;162:1867-1872.

12 Stamler R, Stamler J, Riedlinger WF, Algera G, Roberts RH: Weight and blood pressure. Findings in hypertension screening of 1 million Americans. JAMA 1978;240:1607-1610.

13 Despres JP, Moorjani S, Lupien PJ, Tremblay A, Nadeau A, Bouchard C: Regional distribution of body fat, plasma lipoproteins, and cardiovascular disease. Arteriosclerosis 1990;10:497-511. 


\section{CardioRenal Medicine}

\begin{tabular}{l|l}
\hline Cardiorenal Med 2012;2:314-327 \\
\hline DOI: 10.1159/000343803 & $\begin{array}{l}\text { @ 2012 S. Karger AG, Basel } \\
\text { www.karger.com/crm }\end{array}$ \\
\hline Published online: November 24, 2012 &
\end{tabular}

Jindal et al.: Obesity and the Cardiorenal Metabolic Syndrome: Therapeutic Modalities and Their Efficacy in Improving Cardiovascular and Renal Risk Factors

Bombelli M, Facchetti R, Fodri D, Brambilla G, Sega R, Grassi G, Mancia G: Impact of body mass index and waist circumference on the cardiovascular risk and all-cause death in a general population: data from the PAMELA study. Nutr Metab Cardiovasc Dis 2012, E-pub ahead of print.

Strazzullo P, D’Elia L, Cairella G, Garbagnati F, Cappuccio FP, Scalfi L: Excess body weight and incidence of stroke: meta-analysis of prospective studies with 2 million participants. Stroke 2010;41:e418-e426.

Bogers RP, Bemelmans WJ, Hoogenveen RT, Boshuizen HC, Woodward M, Knekt P, et al: Association of overweight with increased risk of coronary heart disease partly independent of blood pressure and cholesterol levels: a metaanalysis of 21 cohort studies including more than 300000 persons. Arch Intern Med 2007;167:1720-1728.

Whaley-Connell A, Sowers JR: Indices of obesity and cardiometabolic risk. Hypertension 2011;58:991-993.

Hubert HB, Feinleib M, McNamara PM, Castelli WP: Obesity as an independent risk factor for cardiovascular disease: a 26-year follow-up of participants in the Framingham Heart Study. Circulation 1983;67:968-977.

Ejerblad E, Fored CM, Lindblad P, Fryzek J, McLaughlin JK, Nyren O: Obesity and risk for chronic renal failure. J Am Soc Nephrol 2006;17:1695-1702.

Iseki K, Ikemiya Y, Kinjo K, Inoue T, Iseki C, Takishita S: Body mass index and the risk of development of end-stage renal disease in a screened cohort. Kidney Int 2004;65:1870-1876.

Metcalf P, Baker J, Scott A, Wild C, Scragg R, Dryson E: Albuminuria in people at least 40 years old: effect of obesity, hypertension, and hyperlipidemia. Clin Chem 1992;38:1802-1808.

Praga M, Hernandez E, Andres A, Leon M, Ruilope LM, Rodicio JL: Effects of body-weight loss and captopril treatment on proteinuria associated with obesity. Nephron 1995;70:35-41.

Morales E, Valero MA, Leon M, Hernandez E, Praga M: Beneficial effects of weight loss in overweight patients with chronic proteinuric nephropathies. Am J Kidney Dis 2003;41:319-327.

Nenov VD, Taal MW, Sakharova OV, Brenner BM: Multi-hit nature of chronic renal disease. Curr Opin Nephrol Hypertens 2000;9:85-97.

Sowers JR: Metabolic risk factors and renal disease. Kidney Int 2007;71:719-720.

Bray GA, Ryan DH: Medical therapy for the patient with obesity. Circulation 2012;125:1695-1703.

Clinical Guidelines on the Identification, Evaluation, and Treatment of Overweight and Obesity in Adults - The Evidence Report. National Institutes of Health. Obes Res 1998;6(suppl 2):51S-209S.

Wing RR, Marcus MD, Salata R, Epstein LH, Miaskiewicz S, Blair EH: Effects of a very-low-calorie diet on long-term glycemic control in obese type 2 diabetic subjects. Arch Intern Med 1991;151:1334-1340.

Klein S, Fabbrini E, Romijn JA: Williams Textbook of Endocrinology, ed 12, pp 1605-1622.

Foster GD, Wyatt HR, Hill JO, Makris AP, Rosenbaum DL, Brill C, et al: Weight and metabolic outcomes after 2 years on a low-carbohydrate versus low-fat diet: a randomized trial. Ann Intern Med 2010;153:147-157.

Foster GD, Wyatt HR, Hill JO, McGuckin BG, Brill C, Mohammed BS, et al: A randomized trial of a low-carbohydrate diet for obesity. N Engl J Med 2003;348:2082-2090.

Samaha FF, Iqbal N, Seshadri P, Chicano KL, Daily DA, McGrory J, et al: A low-carbohydrate as compared with a lowfat diet in severe obesity. N Engl J Med 2003;348:2074-2081.

Yancy WS Jr, Olsen MK, Guyton JR, Bakst RP, Westman EC: A low-carbohydrate, ketogenic diet versus a low-fat diet to treat obesity and hyperlipidemia: a randomized, controlled trial. Ann Intern Med 2004;140:769-777.

Yancy WS Jr, Almirall D, Maciejewski ML, Kolotkin RL, McDuffie JR, Westman EC: Effects of two weight-loss diets on health-related quality of life. Qual Life Res 2009;18:281-289.

Wylie-Rosett J, Davis NJ: Low-carbohydrate diets: an update on current research. Curr Diab Rep 2009;9:396-404.

Kirk JK, Graves DE, Craven TE, Lipkin EW, Austin M, Margolis KL: Restricted-carbohydrate diets in patients with type 2 diabetes: a meta-analysis. J Am Diet Assoc 2008;108:91-100.

Bantle JP, Wylie-Rosett J, Albright AL, Apovian CM, Clark NG, Franz MJ, et al: Nutrition recommendations and interventions for diabetes: a position statement of the American Diabetes Association. Diabetes Care 2008;31:S61-S78. Thorogood A, Mottillo S, Shimony A, Filion KB, Joseph L, Genest J, et al: Isolated aerobic exercise and weight loss: a systematic review and meta-analysis of randomized controlled trials. Am J Med 2011;124:747-755.

Fagard RH: Physical activity in the prevention and treatment of hypertension in the obese. Med Sci Sports Exerc 1999; 31(11 suppl):S624-S630.

Kaplan LM: Pharmacologic therapies for obesity. Gastroenterol Clin North Am 2010;39:69-79.

Chanoine JP, Hampl S, Jensen C, Boldrin M, Hauptman J: Effect of orlistat on weight and body composition in obese adolescents: a randomized controlled trial. JAMA 2005;293:2873-2883.

Torgerson JS, Hauptman J, Boldrin MN, Sjostrom L: XENical in the prevention of diabetes in obese subjects (XENDOS) study: a randomized study of orlistat as an adjunct to lifestyle changes for the prevention of type 2 diabetes in obese patients. Diabetes Care 2004;27:155-161.

Padwal R, Li SK, Lau DC: Long-term pharmacotherapy for overweight and obesity: a systematic review and metaanalysis of randomized controlled trials. Int J Obes Relat Metab Disord 2003;27:1437-1446.

Lindgarde F: The effect of orlistat on body weight and coronary heart disease risk profile in obese patients: the Swedish Multimorbidity Study. J Intern Med 2000;248:245-254.

Derosa G, Cicero AF, D’Angelo A, Fogari E, Maffioli P: Effects of 1-year orlistat treatment compared to placebo on insulin resistance parameters in patients with type 2 diabetes. J Clin Pharm Ther 2012;37:187-195.

Czernichow S, Lee CM, Barzi F, Greenfield JR, Baur LA, Chalmers J, et al: Efficacy of weight loss drugs on obesity and cardiovascular risk factors in obese adolescents: a meta-analysis of randomized controlled trials. Obes Rev 2010;11: $150-158$. 


\section{CardioRenal Medicine}

\begin{tabular}{l|l}
\hline \multicolumn{2}{l}{ Cardiorenal Med 2012;2:314-327 } \\
\hline DOI: 10.1159/000343803 & $\begin{array}{l}\text { @ 2012 S. Karger AG, Basel } \\
\text { www.karger.com/crm }\end{array}$ \\
\hline Published online: November 24, 2012 &
\end{tabular}

Jindal et al.: Obesity and the Cardiorenal Metabolic Syndrome: Therapeutic Modalities and Their Efficacy in Improving Cardiovascular and Renal Risk Factors

-47 Smith SR, Stenlof KS, Greenway FL, McHutchison J, Schwartz SM, Dev VB, et al: Orlistat 60 mg reduces visceral adipose tissue: a 24-week randomized, placebo-controlled, multicenter trial. Obesity 2011;19:1796-1803.

48 Colman E: Food and Drug Administration's Obesity Drug Guidance Document: a short history. Circulation 2012;125: 2156-2164.

49 Fidler MC, Sanchez M, Raether B, Weissman NJ, Smith SR, Shanahan WR, et al: A one-year randomized trial of lorcaserin for weight loss in obese and overweight adults: the BLOSSOM trial. J Clin Endocrinol Metab 2011;96:30673077.

50 O'Neil PM, Smith SR, Weissman NJ, Fidler MC, Sanchez M, Zhang J, et al: Randomized placebo-controlled clinical trial of lorcaserin for weight loss in type 2 diabetes mellitus: the BLOOM-DM study. Obesity 2012;20:1426-1436.

-51 Smith SR, Weissman NJ, Anderson CM, Sanchez M, Chuang E, Stubbe S, et al: Multicenter, placebo-controlled trial of lorcaserin for weight management. N Engl J Med 2010;363:245-256.

-52 Gadde KM, Allison DB, Ryan DH, Peterson CA, Troupin B, Schwiers ML, et al: Effects of low-dose, controlled-release, phentermine plus topiramate combination on weight and associated comorbidities in overweight and obese adults (CONQUER): a randomised, placebo-controlled, phase 3 trial. Lancet 2011;377:1341-1352.

53 Allison DB, Gadde KM, Garvey WT, Peterson CA, Schwiers ML, Najarian T, et al: Controlled-release phentermine/ topiramate in severely obese adults: a randomized controlled trial (EQUIP). Obesity 2012;20:330-342.

-54 Garvey WT, Ryan DH, Look M, Gadde KM, Allison DB, Peterson CA, et al: Two-year sustained weight loss and metabolic benefits with controlled-release phentermine/topiramate in obese and overweight adults (SEQUEL): a randomized, placebo-controlled, phase 3 extension study. Am J Clin Nutr 2012;95:297-308.

55 Contrave (naltrexone SR/bupropion SR combination) advisory committee briefing document. NDA 200063. Endocrinologic and Metabolic Drugs Advisory Committee Meeting, 2010.

56 Greenway FL, Fujioka K, Plodkowski RA, Mudaliar S, Guttadauria M, Erickson J, et al: Effect of naltrexone plus bupropion on weight loss in overweight and obese adults (COR-I): a multicentre, randomised, double-blind, placebocontrolled, phase 3 trial. Lancet 2010;376:595-605.

57 Wadden TA, Foreyt JP, Foster GD, Hill JO, Klein S, O’Neil PM, et al: Weight loss with naltrexone SR/bupropion SR combination therapy as an adjunct to behavior modification: the COR-BMOD trial. Obesity 2011;19:110-120.

-58 Greenway FL, Dunayevich E, Tollefson G, Erickson J, Guttadauria M, Fujioka K, et al: Comparison of combined bupropion and naltrexone therapy for obesity with monotherapy and placebo. J Clin Endocrinol Metab 2009;94:48984906.

59 Astrup A, Rossner S, Van Gaal L, Rissanen A, Niskanen L, Al Hakim M, et al: Effects of liraglutide in the treatment of obesity: a randomised, double-blind, placebo-controlled study. Lancet 2009;374:1606-1616.

60 Flint A, Raben A, Astrup A, Holst JJ: Glucagon-like peptide 1 promotes satiety and suppresses energy intake in humans. J Clin Invest 1998;101:515-520.

61 Padwal R, Klarenbach S, Wiebe N, Birch D, Karmali S, Manns B, et al: Bariatric surgery: a systematic review and network meta-analysis of randomized trials. Obes Rev 2011;12:602-621.

62 Schauer PR, Kashyap SR, Wolski K, Brethauer SA, Kirwan JP, Pothier CE, et al: Bariatric surgery versus intensive medical therapy in obese patients with diabetes. N Engl J Med 2012;366:1567-1576.

63 Buchwald H, Estok R, Fahrbach K, Banel D, Jensen MD, Pories WJ, et al: Weight and type 2 diabetes after bariatric surgery: systematic review and meta-analysis. Am J Med 2009;122:248-256.

64 Buchwald H, Avidor Y, Braunwald E, Jensen MD, Pories W, Fahrbach K, et al: Bariatric surgery: a systematic review and meta-analysis. JAMA 2004;292:1724-1737.

65 Carlsson LM, Peltonen M, Ahlin S, Anveden A, Bouchard C, Carlsson B, et al: Bariatric surgery and prevention of type 2 diabetes in Swedish obese subjects. N Engl J Med 2012;367:695-704.

66 Rubino F, Forgione A, Cummings DE, Vix M, Gnuli D, Mingrone G, et al: The mechanism of diabetes control after gastrointestinal bypass surgery reveals a role of the proximal small intestine in the pathophysiology of type 2 diabetes. Ann Surg 2006;244:741-749.

67 Flum DR, Dellinger EP: Impact of gastric bypass operation on survival: a population-based analysis. J Am Coll Surg 2004;199:543-551.

68 Bal BS, Finelli FC, Shope TR, Koch TR: Nutritional deficiencies after bariatric surgery. Nat Rev Endocrinol 2012;8: 544-556.

69 Thakar CV, Kharat V, Blanck S, Leonard AC: Acute kidney injury after gastric bypass surgery. Clin J Am Soc Nephrol 2007;2:426-430.

70 de las Fuentes L, Waggoner AD, Mohammed BS, Stein RI, Miller BV 3rd, Foster GD, et al: Effect of moderate dietinduced weight loss and weight regain on cardiovascular structure and function. J Am Coll Cardiol 2009;54:23762381.

71 Wing RR, Lang W, Wadden TA, Safford M, Knowler WC, Bertoni AG, et al: Benefits of modest weight loss in improving cardiovascular risk factors in overweight and obese individuals with type 2 diabetes. Diabetes Care 2011;34:14811486. 